\title{
The use of coconut pulp as a feed substrate to methanogenesis inhibitor in in vitro rumen fluid fermentation
}

\author{
E.H.B. Sondakh, J.A.D. Kalele and F.S. Ratulangi \\ Faculty of Animal Science, Sam Ratulangi University, \\ Jl. Kampus-Bahu, Manado 95115 - Indonesia \\ CorrespondingE-mail: erwin_sondakh@yahoo.com \\ Received December 12, 2016; Accepted May 09, 2017
}

\begin{abstract}
ABSTRAK
Penelitian ini bertujuan untuk mengetahui pengaruh penambahan ampas kelapa pada pakan ruminansia terhadap reduksi metan secara in vitro. Penelitian ini menggunakan cairan rumen dengan substrat hijauan dan konsentrat dengan perbandingan 60:40. Percobaan ini terdiri dari lima macam perlakuan ampas kelapa yakni: R1: tanpa penambahan ampas kelapa; R2: substrat pakan dengan penambahan ampas kelapa 5\%; R3: substrat pakan dengan penambahan ampas kelapa 10\%; R4: Substrat pakan dengan penambahan ampas kelapa 15\% dan R5 substrat pakan dengan penambahan ampas kelapa $20 \%$. Setiap perlakuan dilakukan empat kali ulangan. Fermentasi dilakukan menggunakan Hohenheim Gas Test (HGT) pada suhu $39^{\circ} \mathrm{C}$ selama 72 jam. Pada akhir fermentasi dilakukan pengukuran gas metan, parameter fermentasi, aktivitas mikrobia, kecernaan nutrient dan profil asam lemak cairan rumen. Data dianalisa menggunakan rancangan acak lengkap dan dilanjutkan dengan Duncan test (DMRT) untuk perbedaan rataan. Hasil penelitian menunjukan bahwa produksi metan mengalami penurunan sekitar 13,74\%-17,39 \% ketika pakan diberi ampas kelapa sebanyak 15-20\%. Dari hasil penelitian disimpulkan bahwa pemberian ampas kelapa $15-20 \%$ dalam pakan ruminansia dapat mereduksi gas metan serta tidak mengganggu aktivitas mikrobia pada fermentasi cairan rumen secara in vitro. Supplementasi ampas kelapa tersebut dapat dijadikan acuan dalam mendesain pakan penghambat metanogenik.
\end{abstract}

Kata kunci : metan, ampas kelapa, fermentasi rumen, gas tes, parameter fermentasi

\begin{abstract}
This experiment was conducted to determine the effect of the adding of coconut pulp in ruminant feed on methane reduction in vitro. Rumen fluid and substrate of forage and concentrate in ratio 60:40 were in this study. This experiment consisted of five treatments of coconut pulp as followed: R1: feed substrates without the coconut pulp; R2: substrate feed with coconut pulp 5\%; R3: substrate feed with coconut pulp 10\%; R4: Substrate feed with coconut pulp 15\% and R5: substrate feed with coconut pulp $20 \%$. Each treatment was conducted to four replications. Fermentation was done using the Hohenheim Gas Test (HGT) incubated at $39^{\circ} \mathrm{C}$ for 72 hours. At the end of fermentation was determined production of methane, parameters of fermentation, microbial activity, feed digestibility and fatty acids profile of the ruminal fluid. Data obtained were analyzed by using analysis of variance using completely randomized design. The differences of mean values were analyzed by Duncan multiple range test (DMRT). The results showed that methane production has decreased about $13.74 \%-17.39 \%$ when the feed was given coconut dregs $15-20 \%$. Based on the results of the study was concluded that the supplementation of coconut pulp up to $15-20 \%$ of $100 \%$ dry matter can be used as a substrate of ruminant feed, because it can reduce methane and does not interfere the microbial activity in the fermentation of rumen fluid through in vitro. The supplementation of coconut pulp can be a referencein
\end{abstract}


designing the methanogenic inhibitor feed.

Keywords :coconut pulp, gas tes, methane, parameter of fermentation, ruminal fermentation

\section{INTRODUCTION}

Livestock is considered as the largest contributor of greenhouse gas emissions (methane) in the atmosphere. According to Steinfeld et al. (2006), livestock is the biggest methane contributor in the atmosphere for about $35 \%$. The impact of accumulated methane gas in the atmosphere could cause global warming and the effects on climate change. According to Steinfeld et al. (2006), the calculation of average methane in the last 20 years has increased 72 times greater than $\mathrm{CO}_{2}$. Ironically, today the world precisely focuses on the strategy to reduce $\mathrm{CO}_{2}$ emissions, and only few are concentrating on the reduction of methane emissions.

In the livestock sector, methane is one of gases from fermentation products of feedstuffs by rumen microbes. The methane forming (methanogenic) occurring in the rumen is influenced by protozoa. Methanogen bacteria attach themselves to ciliate protozoa to get a constant supply of hydrogen (Kamra, 2005). Ciliate protozoa is known to have a specific role in the transfer of hydrogen interspecies (Machmuller, 2006; Thalib, 2004; Zhu et al., 2008).

Animal nutritionists are challenged to seek ways in reducing methane production because they feel responsible for the contribution of livestock sector to atmospheric pollution by methane, as one of pollutants that is always associated with ozone depletion and global warming. Efforts to reduce methane gas emissions on ruminants, have been conducted by several researchers such as by the addition of various chemical compounds in livestock rations using fumaric acid, acrylate, 2-oxoglutarate, nitrate, unsaturated fatty acids and anthrakinon (Yusiati et al., 2008). However, the addition of chemicals to the feedstuffs must be very risk, either for the animal itself or food safety. The decrease of methane can also occur when cattle are given feed containing medium chain fatty acids (MCFA) and there has been a study conducted by Machmuller (2006) using canola oil. Sondakh et al. (2015) conducted a research on reducing of methane using virgin coconut oil as a medium chain fatty acids source, in which the results of such research could decrease methane and increase propionic acid in rumen fluid fermentation in vitro. Medium chain fatty acids are fatty acids that function as defaunation agents (Sondakh et al., 2012). Research of Machmuller (2006) and Sondakh et al. (2015) using canola oil and VCO was very expensive and it will be difficult for further applications.

Based on some of the considerations about the role of medium chain fatty acids capable of reducing methane production in ruminal fermentation, so it had been conducted research on the effect of coconut pulp on methane reduction. The use of coconut pulp because coconut pulp contain lots of medium chain fatty acids, as waste and easy to obtain and not compete with human needs. The use of coconut pulp as lowering agents of methane gas production needs to be investigated. Coconut pulp is agricultural waste derived from coconut meat squeezed to be made coconut milk. Coconut meat from wet method processing will obtain byproduct, namely coconut pulp. Coconut pulp has been frequently used as cattle feed as a protein source, especially for non-ruminants. The use of coconut pulp for ruminant feed is rarely done, however the interesting side of coconut pulp is that it contains many MCFA. This study was conducted to obtain the best formula and concentration of coconut pulp as a defaunation agent to ciliate protozoa in reducing methane production with no negative impact on parameters of fermentation and other rumen microbial activities.

\section{MATERIALS AND METHODS}

\section{Materials}

The materials used in this research were ruminal fluid. It was taken from rumen of ruminant (Ongole Grade cattle). The coconut pulp used was taken from mechanical palm oil processing. Substrate used were elephant grass and concentrate (soybean cake, ricebran, coconut pulp). The solution for in vitro test, fermentor, syringe, and waterbath.

\section{Methods}

The supplementation coconut pulp was given 
in this study with treatments as follows: R1: $0 \%$ coconut pulp, $40 \%$ concentrate, $60 \%$ forage); R2: $5 \%$ coconut pulp, $35 \%$ concentrate, $60 \%$ forage); R3 (10\% coconut pulp, 30\% concentrate, $60 \%$ forage); R4 (15\% coconut pulp, $25 \%$ concentrate, $60 \%$ forage); R5 (20\% coconut pulp, 20\% concentrate, $60 \%$ forage). Every treatments was conducted four replications. The feed composition and nutrient ingredients are presented in Table 1.

\section{Procedures}

The medium for fermenting was made by mixing $474.0 \mathrm{~mL}$ of aquades, $0.12 \mathrm{~mL}$ of trace mineral, $237 \mathrm{~mL}$ of buffer, $1.22 \mathrm{~mL}$ of resazurin, and $49.5 \mathrm{~mL}$ of reducer solution. All the materials are homogenized and flowed $\mathrm{CO}_{2}$ at anaerobic conditions. The ratio of ruminal fluid and the medium of fermentation was 1:2(v/v).

Substrate $300 \mathrm{mg}$ (forage and concentrate) were entered into the syringe (fermentation bottle) in accordance with the treatment tested. Insert ruminal fluid have mixed with element solution to $30 \mathrm{~mL}$ into the syringe to test in vitro. The fermentation of anaerob was done for 72 hours at $39^{\circ} \mathrm{C}$. The fluid of fermentation was filtered to separate feedstuffs undegradated to measure methane production, $\mathrm{pH}$ and account of protozoa. After taking for sampling fluid to measure parameter, the filtrate was centrifuged at 3,000 rpm for 15 minutes to determine VFA and $\mathrm{NH}_{3}$. And then, the filtrate was centrifuged again at $10,000 \mathrm{rpm}$ for 15 minutes to measure microbe protein. The residue/sediment was taken to determine biomass based on microbe protein.

\section{Testing of Fermentation Parameters and Rumen Microbe Activity}

After finishing of incubation for 72 hours, a total sample gas volume should be taken $10 \mathrm{~mL}$ using spuit and injected to gas chromatography (GC). GC was used HITACHI 263-50 brand, the column of active carbon of $1 \mathrm{~m}$ of height, diameter of $0.5 \mathrm{~m}$, the detector temperature of $190^{\circ} \mathrm{C}$, injector temperature of $190^{\circ} \mathrm{C}$, the column temperature of $150^{\circ} \mathrm{C}$, and nitrogen gas of 50 $\mathrm{mL} / \mathrm{min}$. $\mathrm{CH}_{4}$ can be measured by following (area of standard $\mathrm{x}$ area of sample)/area of standard (Lopez et al., 1996). The fermented liquid was filtered using a gochcroosh that given glass wool, until no feed sample was left in the syringe. The fermented liquid was used to measure $\mathrm{pH}$. The measurement of $\mathrm{pH}$ used $\mathrm{pH}$ meter. The Preparation of protozoa calculation was done by adding $0.8 \mathrm{~mL}$ of formaldehyde saline solution $(37 \% \mathrm{v} / \mathrm{v})+0.9 \%(\mathrm{v} / \mathrm{v}) \mathrm{NaCl}$, with 1: 9 proportion) at $1 \mathrm{ml}$ sample. And then the sample was calcula0ted by microscopic technique with calculations using a microscope with magnification 40 times (Diaz et al., 1993).

A total of 0.5 centrifugal filtrate of $3000 \mathrm{~g}$ was taken for $\mathrm{NH}_{3}$ (Chaney and Marbach, 1962). Next the sample was centrifuged at $13000 \mathrm{~g}$ for $10 \mathrm{~min}$, then $20 \mu \mathrm{L}$ supernatant sample plus 2.5 $\mathrm{mL} L C$ and added with $2.5 \mathrm{~mL} L D$, then mixed. Next it was incubated in a waterbath with a temperature of $40^{\circ} \mathrm{C}$ for 30 minutes. After the

Table 1. Composition of Feedstuff

\begin{tabular}{lrrrrr}
\hline \multirow{2}{*}{ Variables } & \multicolumn{5}{c}{ Coconut Pulp Added (\% of 100\% Dry Matter) } \\
\cline { 2 - 6 } & \multicolumn{1}{c}{5} & \multicolumn{1}{c}{10} & 15 & 20 \\
\hline Feedstuff (\%) & 60 & 60 & 60 & 60 & 60 \\
$\quad$ Forages & 40 & 35 & 30 & 25 & 20 \\
$\quad$ Concentrate & 0 & 5 & 10 & 15 & 20 \\
$\quad$ Coconut pulp & & & & & \\
Nutrients ingredient (\%) & 17.08 & 17.65 & 17.46 & 17.28 & 17.01 \\
$\quad$ Crude Protein & 5.93 & 5.07 & 5.12 & 5.23 & 5.27 \\
Crude Fat & 23.27 & 23.34 & 23.36 & 24.39 & 24.46 \\
Crude fiber & 42.34 & 43.21 & 43.05 & 42.35 & 43.28 \\
Nitrogen Free Extract & 10.46 & 10.04 & 10.24 & 9.84 & 9.96 \\
Ash & & & &
\end{tabular}


blue is formed, the sample is cooled to room temperature. Furthermore, the reading was done by using $\lambda 630 \mathrm{~nm}$ spectrophotometer. $L C$ is a mixture of phenol $50 \mathrm{mg}$ Na nitroprusside plus 10 gr of crustal phenol so the solution becomes $1 \mathrm{~L}$ with aquades. $L D$ is a mixture of hypochroride, added with $5 \mathrm{~g} \mathrm{NaOH}$ pellet, $26.7125 \mathrm{~g} \mathrm{Na}_{2} \mathrm{HPO}_{4}$ $2 \mathrm{H}_{2} \mathrm{O}$ diluted first with $100 \mathrm{~mL}$ of aquades, and $25 \mathrm{~mL}$ of $5 \%$ sodium hypochloride then mixed and diluted into 1 liter of aquades. The centrifugal filtrate of $3000 \mathrm{~g}$ for 15 minutes was taken a total of $0.2 \mathrm{~mL}$ and added by $1 \mathrm{~mL}$ of metaphosphoric acid, then centrifuged $9000 \mathrm{~g}$ for 10 minutes, the centrifugal sample was used for the measurement of volatile fatty acids (VFA) by gas chromatography (Doreau et al., 1993).

The sediment of centrifugal sample of $13.000 \mathrm{~g}$ was used to measure microbial protein level by using Lowry method according to Plummer (1987). A $0.5 \mathrm{~mL}$ sample was inserted into the test tube and then added $2.5 \mathrm{~mL}$ of Lowry I solution $\left(2 \% \mathrm{Na}_{2} \mathrm{CO}_{3}\right.$ in $0.1 \mathrm{NaOH}, 2 \%$ sodium tartrate, $1 \% \mathrm{CuSO}_{4} 5 \mathrm{H}_{2} \mathrm{O}$, then mixed with a ratio of 100: 1: 1) and ignored at room temperature for 10 minutes. Furthermore, $0.25 \mathrm{ml}$ of Lowry II solution ( $1 \mathrm{~N}$ folin, $\mathrm{H}_{2} \mathrm{O}$, mixed with a ratio of $1: 1$ ) was ignored at room temperature for 30 minutes. Then reading to spectrophotometer at $\lambda 750 \mathrm{~nm}$.

\section{Data Analysis}

The data obtained were statistically analyzed using analysis of variance with a completely randomized design in the direction pattern of each treatment with 4 replications. Differences between treatments were tested by using test Duncan multiple range test (Steel and Torrie, 1980).

\section{RESULTS AND DISCUSSION}

\section{The Production of Methane Gas}

The results of this study showed that the addition of coconut pulp on in vitro fermentation is able to reduce the production of methane gas. The provision of coconut pulp in feed amounting to $15-20 \%$ has significant effects on the formation of methane gas $(\mathrm{P}<0.05)$. The provision of coconut pulp $15 \%$ in $100 \%$ BK can reduce methane gas amounting to $13.74 \%$ and if the coconut pulp is raised up to $20 \%$ in $100 \% \mathrm{BK}$, there will a decrease of $17.38 \%$ when compared to substrates without coconut pulp. Similarly, there is a difference in the average methane gas production on the provision of $10 \%$ and $15 \%$ coconut pulp. The provision of $15 \%$ coconut pulp shows that methane gas production $3.6 \%$ is lower than the provision of $10 \%$ coconut pulp. In this study, the highest decrease is in the provision of $20 \%$ coconut pulp. When compared with the provision of $20 \%$ and $15 \%$ coconut pulp, then the methane gas production has decreased by $4.22 \%$.

It is clearly seen that the influence of coconut pulp levels can reduce methane gas production on in vitro fermentation. The decrease in methane gas production is suspected because of content contained in coconut pulp which contains medium chain fatty acids. Coconut pulp contains about $56 \%$ medium chain fatty acids (Table 2). This fatty acid inhibits the activities of protozoa.

Lauric acid (C12:0) is found to be more effective than myristic acid (C14:0) in suppressing the formation of methane. Myristic acid (C:14) can support the intermediate inhibition effect of lauric acid against methanogenic bacteria and methane gas emission (Soliva et al., 2003). Lauric acid is the most powerful antiprotozoal that inhibits the growth and activity of ciliated protozoa (Hristov et al., 2004). According to Sondakh et al. (2012), the ciliated protozoa is a good place for methanogen bacteria to get nutrients for life sustainability. The decrease of methane gas is closely associated with the presence of protozoa in rumen. Hegarty (1999) states that protozoa is the agent which serves as a unifier between methanogen and its ciliate in a symbiosis manner, so that it causes the formation of methane. Sondakh et al. (2012) reported a study that the provision of MCFA substrate $1.0-1.5 \%$ on in vitro fermentation can decrease the population number of protozoa and can reduce methane gas production.

\section{Activity of Ruminal Microbe}

The Number of Protozoa. The results of this study show that the addition of coconut pulp on in vitro fermentation of rumen fluid can decrease the number of protozoa. There is difference in the number of protozoa $(\mathrm{P}<0.05)$ on the feed added with coconut pulp compared with feed without coconut pulp on in vitro rumen fermentation. The provision of coconut pulp up to $10 \%$ do not lead to differences in the number of protozoa. The decline in the number of protozoa later on occurs in the provision of $15 \%-20 \%$ coconut pulp. The provision of $15 \%-20 \%$ coconut pulp can reduce the number of protozoa by $31 \%-35 \%$ compared with feed substrate that is not given coconut pulp. 
Table 2. Production of Methane Gas at Ruminal Fermentation in vitro with the Addition of Different Level of Coconut Pulp

\begin{tabular}{cccccc}
\hline \multirow{2}{*}{ Replication } & \multicolumn{5}{c}{ Added Coconut Pulp (\% of 100\% Dry Matter) } \\
\cline { 2 - 6 } & 0 & 5 & 10 & 15 & \multicolumn{1}{c}{} \\
\hline 1 & 14.23 & 12.16 & 13.84 & 12.03 & 12.02 \\
2 & 15.37 & 13.21 & 12.03 & 13.8 & 11.1 \\
3 & 13.64 & 14.25 & 13.17 & 12.17 & 11.87 \\
4 & 15.02 & 13.86 & 13.03 & 12.21 & 13.08 \\
Average & $14.55 \pm 0.77^{\mathrm{a}}$ & $13.37 \pm 0.91^{\mathrm{a}}$ & $13.02 \pm 0.74^{\mathrm{a}}$ & $12.55 \pm 0.83^{\mathrm{b}}$ & $12.02 \pm 0.81^{\mathrm{c}}$ \\
\hline
\end{tabular}

Different superscripts in the same row indicate significantly different $(\mathrm{P}<0.05)$

The results of this study indicate that there is a tendency that the number of protozoa decreases along with the addition of coconut pulp. The decline in the number of protozoa is suspected to be caused by the content of medium chain fatty acids contained in coconut pulp. The analysis results of medium chain fatty acid profile consisting of lauric acid and myristic acid in coconut pulp by about $56 \%$. This fatty acid contributes substantially in lowering the number of protozoa on the rumen fluid fermentation. This is in line with what was presented by Machmuller (2006) that medium chain fatty acids can be toxic to ciliated protozoa. The decline in the number of protozoa on the fermentation of rumen which is given substrate containing medium chain fatty acids has been reported by Sondakh et al. (2012) that medium chain fatty acids amounting to 1.0 $1.5 \%$ in $100 \%$ dry matter can reduce the number of protozoa by $29,84 \%$. Likewise, the results of a study reported by Sitoresmi et al. (2009) that the provision of coconut oil up to $5 \%$ can reduce the number of protozoa by $23.95 \%$. Machmuller (2006) and Dohme et al. (1999) states that medium chain fatty acid is the most powerful antiprotozoal that inhibits the growth and activity of ciliate protozoa (entodiniumspp). The content of lauric acid contained in the medium chain fatty acids can increase the microbial sensitivity on cell wall, which causes inhibition of ciliate protozoa and gram-positive of archaea.

Microbial protein. The effect of giving coconut pulp with different levels on the microbial protein synthesis in vitro can be seen in Table 3. The results show that the provision of coconut pulp up to $20 \%$ in $100 \%$ dry matter has not led to changes in the microbial protein synthesis. The provision of $0-20 \%$ coconut pulp on the substrate of forage feed and concentrates with a ratio of $60: 40$ is in the range of $0.29-0.37$ $\mathrm{mg} / \mathrm{mL}$. This study is in line with a research from Sitoresmi et al. (2009) stating that the addition of coconut oil up to $7.5 \%$ could not bring an effect on microbial protein synthesis, microbial protein synthesis is in the range of $0.38-0.39 \mathrm{mg} / \mathrm{mL}$. The results of this study are still far below the results of research conducted by Yusiati et al. (2008), which states that the addition of lemuru fish oil up to level of $7.5 \%$ dry matter on the fermentation of king grass and fine bran with a ratio of $80: 20$ in vitro has microbial protein synthesis on the range of $0.51-0.56 \mathrm{mg} / \mathrm{mL}$. Precursor for microbial protein synthesis depends on the availability of sufficient carbon chain, $\mathrm{NH} 3$ and energy. Pathak (2008) states that microbial protein is the main source of amino acid supply for ruminants. The contribution of microbial protein amounted to $30-50 \%$ of the total protein utilized by ruminants. Orskov (1992) stated that precursor for the synthesis microbial proteins ie the availability of sufficient carbon, $\mathrm{NH}_{3}$ and energy. The ideal conditions of microbial protein synthesis will be achieved if the fermentable carbohydrate source is available simultaneously with the protein source.

\section{Parameter of Ruminal Fermentation}

Ammonia $\left(\mathbf{N H}_{3}\right)$. The effect of giving coconut pulp up to $20 \%$ from $100 \%$ dry matter has not led to difference in $\mathrm{NH}_{3}$ on the fermentation of rumen fluid in vitro using substrates of elephant grass and concentrates 
(Table 4). The provision of coconut pulp up to $20 \%, \mathrm{NH}_{3}$ is in the range of $24.49-27.81 \mathrm{mg} / 100$ $\mathrm{mL}$. The results of this study are still far below the results of research conducted by Sitoresmi et al. (2009) stated that the level of ammonia $\left(\mathrm{NH}_{3}\right)$ on the addition of oil up to $7.5 \%$ ranges from 33.24- $34.53 \mathrm{mg} / 100 \mathrm{~m}$. Owen and Zinn (1988) stated that concentration of $\mathrm{NH}_{3}$ varies greatly depending on the magnitude of feed degradation. The excessive production of $\mathrm{NH}_{3}$ is not beneficial to the formation of microbial protein and will be discarded. Ammonia is the result of protein degradation by proteolytic bacteria which will then be used by the components to form microbial protein. The decrease in protein degradation of feed will be followed by a decrease in ammonia produced.

Volatile Fatty Acids. The results of this study show that the provision of coconut pulp has an effect on propionate acid. There is an increase of propionic acid content in line with the higher level of coconut pulp provision. However, unlike acetic and butyric acids, the provision of coconut pulp up to $20 \%$ from $100 \%$ dry matter (DM) has not shown any difference. Likewise, the ratio of acetate propionate has not given any different effect. The improvement of propionic acid begins with the provision of $10 \%$ to $20 \%$ coconut pulp in $100 \% \mathrm{BK}$ on the fermentation of rumen fluid. There is an increase in propionate acid by $33.8 \%$ $36.0 \%$ in the provision of $10-20 \%$ coconut pulp in $100 \%$ BK. The provision of coconut pulp leads to a difference in the average of propionate profile. The difference in the average of propionate content when given coconut pulp is allegedly because of the coconut pulp that can lower methane content (Table 3). According to Sondakh et al. (2012), there was a correlation between the decrease in methane gas production and increase in propionic acid on the fermentation of rumen

Table 3.The Number of Protozoa and Microbe Protein Synthesis in in vitro Ruminal Fermentation with Addition of Different Level of Coconut Pulp

\begin{tabular}{lccccc}
\hline Variables & \multicolumn{5}{c}{ Added Coconut Pulp (\% of 100\% Dry Matter) } \\
\cline { 2 - 6 } & 0 & 5 & 10 & 15 & 20 \\
\hline Number of protozoa $\left(\mathrm{x} 10^{3}\right)$ & $8778 \pm 11^{\mathrm{a}}$ & $7543 \pm 1496^{\mathrm{a}}$ & $6621 \pm 881^{\mathrm{a}}$ & $6086 \pm 1395^{\mathrm{b}}$ & $5863 \pm 692^{\mathrm{b}}$ \\
Microbe protein $(\mathrm{mg} / \mathrm{mL})^{\mathrm{ns}}$ & $0.29 \pm 0.04$ & $0.31 \pm 0.07$ & $0.33 \pm 0.06$ & $0.34 \pm 0.07$ & $0.37 \pm 0.08$ \\
\hline
\end{tabular}

ns $=$ non significant

Different superscripts in the same row indicate significantly different $(\mathrm{P}<0.05)$

Table 4. Parameter of in vitro Ruminal Fermentation with Addition of Different Level of Coconut Pulp

\begin{tabular}{lccccc}
\hline \multirow{2}{*}{ Parameter } & \multicolumn{5}{c}{ Added Coconut Pulp (\% of 100\% Dry Matter) } \\
\cline { 2 - 6 } & \multicolumn{1}{c}{0} & \multicolumn{1}{c}{5} & \multicolumn{1}{c}{10} & 15 & \multicolumn{1}{c}{20} \\
\hline $\mathrm{NH}_{3}(\mathrm{mg} / 100 \mathrm{~mL})^{\mathrm{ns}}$ & $37.75 \pm 0.45$ & $36.61 \pm 1.34$ & $36.51 \pm 6.14$ & $35.59 \pm 0.49$ & $41.42 \pm 1.76$ \\
VFA & & & & & \\
Asetic $^{\mathrm{ns}}$ & $14.30 \pm 1.60$ & $13.74 \pm 0.80$ & $14.12 \pm 0.90$ & $14.25 \pm 1.00$ & $13.85 \pm 0.90$ \\
Propionic & $3.75 \pm 0.38^{\mathrm{a}}$ & $4.00 \pm 0.80^{\mathrm{a}}$ & $5.02 \pm 0.58^{\mathrm{b}}$ & $5.07 \pm 0.55^{\mathrm{b}}$ & $5.10 \pm 0.74^{\mathrm{b}}$ \\
Butyric $^{\mathrm{ns}}$ & $1.53 \pm 0.23$ & $1.51 \pm 0.10$ & $1.49 \pm 0.75$ & $1.55 \pm 0.90$ & $1.71 \pm 0.27$ \\
Asetic:Propionic & $3.83 \pm 0.45$ & $3.57 \pm 0.89$ & $2.85 \pm 0.52$ & $2.85 \pm 0.52$ & $2.77 \pm 0.59$ \\
$\mathrm{pH}^{\mathrm{ns}}$ & $6.6 \pm 0.10$ & $6.8 \pm 0.30$ & $7.0 \pm 0.20$ & $6.9 \pm 0.30$ & $6.8 \pm 0.30$ \\
\hline
\end{tabular}

ns $=$ non significant

Different superscripts in the same row indicate significantly different $(\mathrm{P}<0.05)$ 
fluid. This is in line with what was stated by Wang et al. (2009) that VFA concentration has an influence on the methane production in rumen. Similarly, Hu et al. (2005) stated that defaunation process causes VFA concentration declining, but propionate molar increases.

Degree of Acidity (pH). The results of research show that provision of coconut pulp up to $20 \%$ in $100 \%$ dry matter (DM) on the fermentation of rumen in vitro has not led to changes in $\mathrm{pH}$ of rumen fluid. In this study, ruminal $\mathrm{pH}$ is stable on the range of 6.6-7.0. The $\mathrm{pH}$ value on the fermentation of rumen fluid which is in vitro associated with the methane production has been reported also by Sitoresmi et al. (2009); Harwanto et al. (2014). The researchers stated that the fermentation of rumen fluid in vitro uses feed substrate which allegedly can reduce methane production, has not led to changes in $\mathrm{pH}$ value. Krause et al. (2002) stated that $\mathrm{pH}$ value is influenced by the concentration of fiber in the feed. The $\mathrm{pH}$ value of rumen varies; feed containing grains can lower the $\mathrm{pH}$ value to below 5, while feed that contains a lot of fiber can cause an increase in $\mathrm{pH}$ to above 7 . According to Owen and Zinn (1988), the range of normal pH for the activity of rumen microbes to degrade feed and carry out the process of fermentation is 5.57.6. This statement was also confirmed by researcher (Harwanto et al., 2014; Keidane and Birgile, 2003) that ruminal fermentation survival at level $\mathrm{pH}$ 6.0-8.0.

\section{CONCLUSION}

Based on the results of the study, it can be concluded that the supplementation of coconut pulp up to $15-20 \%$ of $100 \%$ dry matter can be used as a substrate of ruminant feed, because it can reduce methane and does not interfere the microbial activity in the fermentation of rumen fluid through in vitro. The supplementation of coconut pulp can be a reference in designing the methanogenesis inhibitor feed.

\section{ACKNOWLEDGMENTS}

The appreciation and gratitude are conveyed to the Directorate General of Higher Education who has provided funding for fundamental research in 2016, thanks to the Dean and head of Laboratory of Biochemistry of Faculty of Animal Science Universitas Gadjah Mada who have given the opportunity to conduct research.

\section{REFERENCES}

Chaney, A.L. and E.P. Marbach. 1962. Modified reagents for determination of urea and ammonia. Clin. Chem. 8:130-132.

Diaz, A., M. Avendano and A. Escobar. 1993. Evaluation of Sapindus Saponaria as a Defaunating Agent and Its Effects on Different Ruminal Digestion Parameters. Livest. Res. Rural Dev. 5(2):1-6.

Dohme, F., A. Machmuller, B.L. Esterman, P. Pfister, A.Wasserfallen and M. Kreuzer. 1999. The Rule of the rumen protozoa for methane suppression caused by coconut oil. Lett. App. Microbiol. 29:87-192.

Doreau, M., B. Salem and R.R. Krezminski. 1993. Effect of rapeseed oil supply on in vitro ruminal digestion in cows: comparison of hay and maize silage diets. Anim. Feed Sci Technol. 44:181-189

Harwanto, L.M. Yusiati and R. Utomo. 2014. Pengaruh kayumanis (Cinnamomumburmanni Ness ex BI.) sebagai sumber sinamaldehid terhadap parameter fermentasi dan aktivitas mikrobia rumen secara in vitro. Buletin Peternakan 38(2):71-77

Hegarty, R.S. 1999. Reducing rumen methane emissions through elimination of rumen protozoa. Aust J. Agr. Res. 50:1321-1328.

Hristov, A.N., M. Ivan and T.A. McAllister. 2004. In vitro effects on individual fatty acids on protozoal numbers and on fermentation products in ruminal fluid from cattle fed a high concentrate, barley-based diet. J. Anim. Sci. 82:2693-2704.

Hu, W.L., Y.M. Wu, J.X Liu, Y.Q Guo and J.A. Ye. 2005. Tea saponins affect in vitro fermentation and methanogenesis in faunated and defaunated rumen fluid. $J$. Zhejiang Univ. Sci. 6(B):787-792.

Kamra, D.N. 2005. Rumen microbial ecosystem. Special edition: Microbial Diversity. Current Sci. 89:124-135.

Keidäne, D and E. Birǵele. 2003.The efficacy of feed on the intra abomasal $\mathrm{pH}$ dynamics in goats. Veterinarija IR Zootechnica 22:58-61

Krause, K.M., D.K. Combs and K.A. Beauchemin. 2002. Effects of forage particle size and grain fermentability in midlactation cows. II. Ruminal $\mathrm{pH}$ and Chewing Activity. J. Dairy Sci. 83: 879-889

Lopez, P., M.L. Kung Jr. and J.M. Odom. 1996. In vitro of microbial methane production by 9,10-anthraquinone. Anim. Feed Sci. 
Technol. 71: 117-130.

Machmuller, A. 2006. Medium-chain fatty acids and their potensial to reduce methanogenesis in domestic ruminants. Agr. Ecosyst. Environ. 112:107-114.

Owen, F.N. and R. Zinn. 1988. Protein metabolism of Ruminant animals. In: D.C. Church (Ed), The Ruminant animal Digestive physiology and Nutrition. Reston Book Prentice Hall, Englewood Cliffs, New Jersey.

Orskov, E.R. 1992. Protein Nutrition in Ruminant. Academic Press Limited. London

Pathak, A.K. 2008. Various factor affecting microbial protein synthesis in rumen. Vet. World. 1(6):186-189.

Plummer, D.T. 1987. An Introduction to Practical Biochemistry. $3^{\text {rd }}$ ed. McGraw-Hill Book Company. London.

Sitoresmi, P.D., L.M. Yusiati and H. Hartadi. 2009. Pengaruh penambahan minyak kelapa, minyak biji matahari, dan minyak kelapa sawit terhadap penurunan produksi metan di dalam rumen secara in vitro. Buletin Peternakan. 33(2):96-105.

Soliva, C.R., I.K. Hindrichsen, L. Meile, M. Kreuzer and A. Machmuller. 2003. Effect of mixture of lauric and myristic acid on rumen methanogens and methanogenesis in vitro. Lett. Appl. Microbiol. 37:35-39.

Sondakh, E.H.B., L.M. Yusiati, H. Hartadi and E. Suryanto. 2012. Bungkil kelapa sumber medium chain fatty acids dalam pakan ruminansia sebagai agensia penurun gas metan pada fermentasi rumen secara in vitro. Agrinimal. 2 (2):39-43

Sondakh, E.H.B., J.A. Rorong and J.A.D. Kalele.
2015. Methane gas reduction using virgin coconut oil supplementation in rumen fermentation through in Vitro. J. Anim. Prod. 17(3):144-148.

Steel, R.G.D. and J.H. Torrie. 1980. Principles and Procedures of Statistics. McGraw-Hill Book Co. Inc. New York.

Steinsfeld, H., P. Gerber, T. Wassenaar, V. Castel, M. Rosales and C. deHaan. 2006. Livestock's Long Shadow. Food and Agriculture Organisation of The United Nation. Rome.

Thalib, A. 2004. Uji efektivitas saponin buah sapindus rarak sebagai inhibitor metanogenesis secara in vitro pada sistim pencernaan rumen. Jurnal Ilmu Ternak dan Veteriner. 9(3):164-171.

Wang, Y., Y. Zhang, J. Wang and L. Meng. 2009. Effects of volatile fatty acid concentrations on methane yield and methanogenic banteria. J. Biomass. Bioenergi. 33: 48- 853.

Yusiati, L.M., Z. Bachrudin, C.Hanim and E. Lestari. 2008. The effect sardine (sardinellelongiceps) oil as a sources of methanogenesis inhibitor agent on the rumen fermentation product of the diet containing different level of forages. In: Management Strategy of Animal Health and Production Control on Anticipation Global Warming for Achievment of Millenium Development Goals. Faculty of Veterinary Medicine Airlangga University. P. 181-185.

Zhu, W.Y., M.F. Iqbal, Y.F. Cheng, J.X. Liu and S.Y. Mao. 2008. Rumen methanogenesis and nutritional approaches to the mitigation of ruminant methane. Asian-Australas. J. Anim. Sci. 13:33-40. 